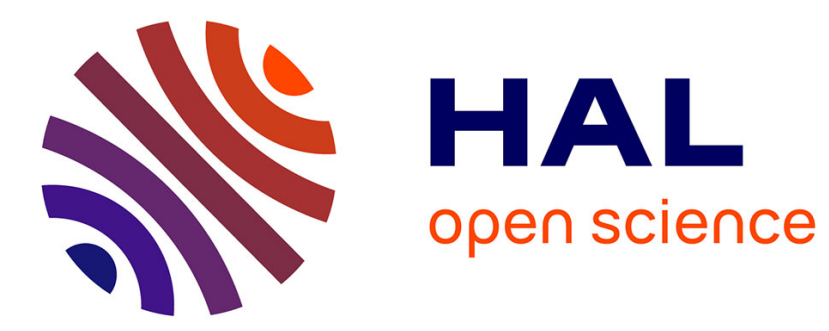

\title{
Introduction: Illegal Trades across National Borders Pierre-Arnaud Chouvy
}

\section{To cite this version:}

Pierre-Arnaud Chouvy. Introduction: Illegal Trades across National Borders. An Atlas of Trafficking in Southeast Asia. The Illegal Trade in Arms, Drugs, People, Counterfeit Goods and Natural Resources in Mainland Southeast Asia, IB Tauris, p. 1-33, 2013. hal-01048590

\section{HAL Id: hal-01048590 \\ https://hal.science/hal-01048590}

Submitted on 25 Jul 2014

HAL is a multi-disciplinary open access archive for the deposit and dissemination of scientific research documents, whether they are published or not. The documents may come from teaching and research institutions in France or abroad, or from public or private research centers.
L'archive ouverte pluridisciplinaire HAL, est destinée au dépôt et à la diffusion de documents scientifiques de niveau recherche, publiés ou non, émanant des établissements d'enseignement et de recherche français ou étrangers, des laboratoires publics ou privés. 
An Atlas of Trafficking in Southeast Asia:

The Illegal Trade in Arms, Drugs, People, Counterfeit Goods, and Natural Resources

in Mainland Southeast Asia

\title{
Introduction: Illegal Trades across National Borders
}

\author{
Pierre-Arnaud CHOUVY
}

Mainland Southeast Asia — or Indochina as it has long been known owing to its position between India and China (see map 1) — has been marked by decades of trafficking in illegal goods. Illegal trades in mainland Southeast Asia are numerous, highly diverse, and most likely increasingly complex. Of course, two of the most prominent illegal trades defining the area are human trafficking and drug trafficking, human trafficking in relation, notably, to the extensive regional prostitution market it feeds, with Thailand being infamous the world over for that reason; and drug trafficking in relation to opium and heroin produced in bulk within the similarly ill-famed Golden Triangle. Complexity arises from the fact that human trafficking and drug trafficking can be said to be linked in some places and to some extent, whether drug consumption by prostitutes - and by many of their clients-is concerned or whether economic havoc created by excessively brutal and rapid eradication of illegal crops pushes women into prostitution. However, as we will see, complexity is likewise increased by the fact that many other illegal trades feed off these two major trafficking activities and their sometimes congruous networks. Some of these trades may, at some point, contribute to one another; they may also proceed, to some extent, from propitious specific regional dynamics 
(trafficking in drugs and arms in the context of armed conflicts for example). It is this great diversity and complexity of illegal trading across mainland Southeast Asia that this book addresses, focusing on five of its most pervasive phenomenon: drug trafficking, human trafficking, arms trafficking, wildlife and timber trafficking, and the trade in counterfeit goods and contraband.

As might be expected, the peninsular mass of mainland Southeast Asia is not only one of Asia's historical major crossroads (hence "Indochina" and the French Indochine). It is also famous worldwide as the site of the so-called Golden Triangle, one of the two main areas of illegal opium production in Asia and one of the largest in the world for that matter. But, insofar as illegal activities are concerned, contemporary mainland Southeast Asia is known not only as a locus of illegal drug production but also as a drug trafficking hub and a significant drug consumer market. Heroin and methamphetamine are produced mainly in Burma (also known as Myanmar since 1988) and trafficked heavily throughout the region. Heroin and methamphetamine may be consumed regionally (both in mainland and in insular Southeast Asia) or may be exported to China (via the province of Yunnan), to India (via its northeastern states), or overseas, mostly to Japan, Australia, and North and South America (see map 13).

However, many other trafficking or smuggling activities have long occurred in and throughout mainland Southeast Asia while others are now in the process of being developed. One of them, constantly increasing both regionally and worldwide, is human trafficking. This activity shares many features with drug trafficking and, although statistics are unreliable and trustworthy studies remain scant, it is frequently mentioned as becoming the world's largest illegal economy. Again, though, the assertion is unverifiable since no one can reasonably provide a precise estimate of the global value of drug trafficking alone ${ }^{1}$. In any case, Southeast Asia also experiences many other major smuggling and trafficking activities, from 
the international trade in small arms and in nuclear and other radioactive materials, to the international trade in illegally logged timber, forest products and wildlife. It is at once worth noting that some of these traffics can be distinguished from many others insofar as they constitute instances of environmental harm and predatory activities or both.

However, while seizures conducted throughout the region attest to the existence of various and numerous smuggling and trafficking activities, the scope, diversity, nature and mechanisms of the overall phenomenon are far from being satisfactorily studied and understood. In fact, the very complexity of the phenomenon goes beyond its diversity and fast-evolving trends as the extent of the illegal trades undoubtedly exceeds what is known and understood from open or even restricted sources. This condition owes largely to the relative failure of concerned authorities and bodies, both at the national and international level, to monitor illegal movements across national borders. Yet it is also the result of a general deficit in academic research on these issues and of the segmentation of most of the research that has been undertaken. The various studies of illegal trades do not provide a regional and systemic understanding of the variety of smuggling and trafficking activities. Even less is known of the synergies that are likely to exist between drug trafficking, human smuggling and trafficking, arms trafficking, wood smuggling, etc. As Itty Abraham and Willem van Schendel explain, there is a "problem of compartmentalization, as specialists in small arms and drugs rarely communicate, and scholars of smuggling, trafficking, and money laundering have no common forum to share their insights, all preventing a comprehensive landscape of the scale of illegal activities from being visualized"2.

Still, smuggling and trafficking activities have been drawing increased attention during the past decade or so, as globalization further opened and deregulated national and regional markets. Trafficking is increasingly being presented as a growing threat in the media as well as in governmental and non-governmental reports. This is not only because, as Itty Abraham 
and Willem van Schendel put it, "individuals and social groups that systematically contest or bypass state controls [...] flout the letter of the law" and sometimes jeopardize public health (illegal drugs, counterfeit pharmaceuticals), the environment (illegal logging and poaching), social fabrics (human smuggling and trafficking), or even peace (arms trafficking). In fact, states see trafficking activities as a major threat also because smugglers and traffickers "bring into question the legitimacy of the state itself by questioning the state's ability to control its own territory" ${ }^{3}$. Whether smuggling and trafficking activities are clearly on the rise or whether greater attention has been paid by national and international authorities, the phenomenon nowadays is more and more presented as a major multi-fold and worldwide threat.

But, while globalization has undoubtedly and increasingly transformed the phenomenon during recent decades, the historical and geographical approach of notions such as borders, frontiers and routes, shows us that the phenomenon is far from being entirely new. History shows that the rise of the nation-state and its multiple regulations have directly affected various types and ways of trading by rendering them illegal. Thus, to shed some light on what is, by essence, a complex and shadowy world made of illegal and therefore absconded activities one must first understand how "the politics of access and of its denial" ${ }^{4}$ have been deeply affected by the modern modification of frontiers, borders, routes and regulations. But, firstly, the widely used notions of smuggling and trafficking need to be distinguished from each other and explained, in order to show that although both activities amount to illegal trading, smuggling is not trafficking.

\section{Smuggling or trafficking?}

One major distinction must be made between the different activities that amount to illegal trading. Illegal trades can be distinguished according to the nature of the goods that are exchanged as well as to the nature of the trade itself. Therefore, distinguishing between 
smuggling and trafficking enables us to dissociate two major types of illegal trading and to overcome the confusion of two terms that are frequently used interchangeably and without distinction. To that effect, one can build on the work of David Bevan, Paul Collier and Jan Gunning $^{5}$, who separate what they call "black goods" (goods that are illegal) and "black parallel markets" (where legal goods are being traded illegally). Another interesting and useful distinction has been made by Abraham and Van Schendel who "build up a distinction between what states consider to be legitimate ("legal") and what people involved in transnational networks consider to be legitimate (licit)". As the authors explain, this distinction is most useful in the context of an "approach to issues of legality and illegality which does not take the state as its point of departure"6. Yet, raising issues of legitimacy in this book would have made things even more complicated than they already were (rights of individuals to consume drugs, own guns, poach, log, mine, illegally and willingly across international border, etc.) and it was thought here that focusing on what made some cross border activities illegal according to national laws was a better choice, which does not mean that the perceptions of borders and borderlanders have been dismissed altogether.

Hereafter, smuggling will describe the importation and, or, exportation of legal goods contrary to the law of at least one country, especially when duties are not paid or when part of a regulation is not observed. As for trafficking, it will describe a trade in goods that are illegal per se; that is, a trade therefore illegal by definition. Thus trading in heroin differs greatly from trading in cigarettes since heroin is an illegal product and cigarettes are produced and sold legally. Nevertheless, cigarette smuggling is rampant in the world, for instance in the European Union, owing to great variation in duties and ages of legal consumption from country to country. Therefore, duties, regulations and prohibition partly determine the extent to which goods are smuggled or trafficked, whether locally, regionally or globally ${ }^{7}$. Of course, goods that are considered "licit" by people involved in transnational networks are 
more likely to be smuggled and, or, trafficked, than goods deemed "illicit", whether they are legal or not.

Usually, the difference between smuggling and trafficking is made only concerning the trade in human beings. According to the United Nations Office on Drugs and Crime (UNODC), human smuggling and human trafficking are similar in some respects, but bear several important differences. The United Nations Protocol Against the Smuggling of Migrants by Land, Sea and Air, Supplementing the United Nations Convention Against Transnational Organized Crime, defines the "smuggling of migrants" as "the procurement, in order to obtain, directly or indirectly, a financial or other material benefit, of the illegal entry of a person into a State Party of which the person is not a national or permanent resident." The United Nations Protocol to Prevent, Suppress and Punish Trafficking in Persons defines "trafficking in persons" as "the recruitment, transportation, transfer, harbouring or receipt of persons, by means of the threat or use of force or other forms of coercion, of abduction, of fraud, of deception, of the abuse of power or of a position of vulnerability or of the giving or receiving of payments or benefits to achieve the consent of a person having control over another person, for the purpose of exploitation. Exploitation shall include, at a minimum, the exploitation of the prostitution of others or other forms of sexual exploitation, forced labour or services, slavery or practices similar to slavery, servitude or the removal of organs." Thus, trafficked victims, according to the UNODC, "have either never consented or, if they initially consented, that consent has been rendered meaningless by the coercive, deceptive or abusive actions of the traffickers." Another major difference, according to the UNODC, is that "smuggling ends with the arrival of the migrants at their destination, whereas trafficking involves the ongoing exploitation of the victims in some manner to generate illicit profits for the traffickers." 
Thus, according to the United Nations, what distinguishes human smuggling from human trafficking, which are both illegal practices and designate illegal movements of persons, is coercion (or, alternatively, absence of consent). While both smuggled and trafficked people are illegal immigrants, only the first are compliant and complicit, unless, of course, initial consent is nullified by deception and, or, coercion ${ }^{8}$. The extreme complexity of human smuggling and trafficking is notably determined by the fact that activities fed by illegal migration - as diverse as prostitution, mining, or even begging - can be either coerced or consented activities: prostitution can be voluntary, while forced labour can be used in mines. Children, who are increasingly being trafficked, can be abducted to become beggars in a foreign country. Moreover, as is the case in Southeast Asia, countries are frequently source, transit and destination areas for trafficked persons, depending on the segmentation of national and regional markets ${ }^{9}$.

Other migrants (emigrants or immigrants) can also be said to be illegal or to have been illegally moved from one place to another, for example refugees (as immigrants) and adopted children (both as emigrants and immigrants). Refugees often cross international borders without proper paperwork but while this kind of illegal immigration is forced, it surely must not be viewed as being criminal, for a refugee, while not always benefiting from having refugee status, is frequently exposed to physical violence and economic exploitation. This is a global phenomenon, despite the United Nations High Commissioner for Refugees (UNHCR) using the 1951 Geneva Refugee Convention as its major tool to ensure the basic human rights of vulnerable persons, particularly toward guaranteeing that refugees will not be returned involuntarily to a country where they face persecution.

It is worth noting that children, being especially vulnerable, are among the first victims of human trafficking. For instance, Xin Ren alleges that "trafficking in children for sale, sexual exploitation, child pornography, and slavery labour has become one of the fastest growing 
global crime enterprises stretching from the African continent to Europe and from AsiaPacific to North and South America". Children are being "sold, abducted, kidnapped, or lured away from their families, bought, exploited, abused or even murdered for profits and illicit services" ${ }^{10}$. Of course, trafficking in children can occur in various contexts, with many different push and pull factors. For example, illegal adoption is an international phenomenon in which local and global push and pull factors can be closely intertwined. Whether for domestic or international markets, "trafficking in children in China is largely for domestic illegal adoption that is driven by a deeply rooted traditional belief that only male heirs can carry on the family name and sonless marriage is a moral shame that disgraces one's ancestors"11. But since legal adoption may prove extremely difficult in Western countries, because of strict laws aimed at child protection, and because regulation acts as a strong incentive for traffickers, worldwide illegal child adoption has become a highly lucrative market.

Children, as well as men and women, furthermore can be abducted, trafficked and killed for forced organ removal for transplant purposes, as high prices paid for kidneys, as just one example, drive an extremely profitable global market. However, because sex workers are in such great demand worldwide, it appears that $50 \%$ of trafficked persons in the world are children, and that $70 \%$ are women ${ }^{12}$. As stated by Vitit Muntarbhorn, the former UN Special Rapporteur on the Sale of Children, Child Prostitution and Child Pornography, "the world community is faced with a rampant and perverse sex market which wreaks havoc on a multitude of children" ${ }^{\prime 13}$. Indeed, ECPAT ${ }^{14}$, an international non-governmental organization working to "End Child Prostitution, Child Pornography and Trafficking in Children for sexual purposes", reports that there are more than 1 million child prostitutes involved in sex tourism in Asia, of which 300,000 are in Thailand, 100,000 in the Philippines and Taiwan and 40,000 in Vietnam ${ }^{15}$. 
In May 2005, in a report that has been termed "the most comprehensive analysis ever undertaken by an intergovernmental organization of the facts and underlying causes of contemporary forced labour", the International Labour Organisation (ILO) revealed that "at least 12.3 million people were trapped in forced labour around the world" and that "children aged less than 18 years bear a heavy burden, comprising 40 to 50 per cent of all forced labour victims". If we refer to the aforementioned definition provided by the United Nations Protocol to Prevent, Suppress and Punish Trafficking in Persons, exploitation through forced labour is a fundamental dimension of human trafficking. This is something that the ILO report also points to when confirming something that had often been hinted at by less comprehensive studies: that forced labour, human trafficking and the sex industry, were closely linked. In fact, according to ILO, at least one-fifth of the world's 12 million bonded labourers are victims of illegal human trafficking - mainly for the sex industry. For instance, the report details, "Forced economic exploitation in such sectors as agriculture, construction, brick-making and informal sweatshop manufacturing is more or less evenly divided between the sexes". However, "forced commercial sexual exploitation entraps almost entirely women and girls"16.

Smuggling and trafficking, then, are different, no matter what trade (human beings or commercial goods) is concerned. As we will see, the very dimensions and impact of smuggling and trafficking also differ, mainly depending on the consequences of the illegal trade on source, transit and destination countries. However, to better understand smuggling and trafficking activities, one first needs to learn about borders, routes, and their respective logics. Indeed, smuggling and trafficking consist of illegal border crossings made via various routes or lines of travel, namely trails, paths, roads, and the like.

Of routes, frontiers and borders: the politics of access 
A border, through its definition and its delimitation processes, modifies the very nature of any traditional trading that preceded its imposition. In fact, for many merchants, activities suddenly termed smuggling or trafficking are nothing else than traditional trading turned illegal or traditional goods turned illegal; for instance "what is now called smuggling was normal among the Pashtun nomads of eastern Afghanistan for many generations" ${ }^{17}$. Indeed, according to a Pakistani Afridi from the Northwest Frontier Province (NWFP) of Pakistan: "You might call what we do smuggling. But to us, it's just trade" ${ }^{18}$. Between Afghanistan and Pakistan, as well as between Burma and Thailand, imposed boundaries cut through frontier zones and tribal land, changing frontiers into borders and creating de facto jurisdictions-in effect, bounded legal territories. But boundaries also affect the very nature or existence of routes. For example, "a road through tribal territory is much more than an avenue of mobility. Here the laws of the state intersect with the laws of the tribe" ${ }^{, 19}$. As David Ludden explains, "Modernity consigned human mobility to the dusty corners of archives that document the hegemonic space of national territorialism. As a result, we imagine that mobility is border crossing, as though borders came first and mobility second"20.

As stressed in the work of Mahnaz Ispahani, a route is "both a geographical and a political idea, both an end and a means". Her study of "the politics of access in the borderlands of Asia" draws on the work of the French geographer Jean Gottmann who stated that "one of the major aims of politics is to regulate the conditions of access". Opposing the route is what Mahnaz Ispahani calls the antiroute: "any natural or artifical constraint on access", ranging from mountains and deserts to "legal boundaries and tariffs that raise the cost of crossing them". Antiroutes, as she rightly observes, "may serve the same human purposes as routes", that is, to regulate the conditions of access. Indeed, "what routes move, and what antiroutes prevent from moving, are people and goods within and across frontiers" ${ }^{21}$. And routes are consubstantial to borders since "without land routes, borders cannot be defined and secured". 
Ispahani continues, "Whereas states cannot come into existence without the ability to deny access, they cannot be physically consolidated and politically sustained without the ability to expand access-without the extension of the authority and the legitimacy of the center to the peripheries" 22 .

As Lord Curzon, Governor General and Viceroy of India (1899-1905), remarked, "the earliest frontiers 'erected a barrier or created a gap', that is, restricted movement and access" $^{, 23}$. What was true in the borderlands of Southwest Asia, and for its borderlanders, can also be osberved in the frontier area that stretched between Burma and Siam in the $19^{\text {th }}$ century. When the British raised the question of the western frontier of Siam, in the early $19^{\text {th }}$ century, no document or treaty identifying and delimitating the boundary could be provided by the local chiefs, as Thongchai Winichakul explains: "as these were friendly neighbors who shared understanding and trust, one local chief replied, the boundary did not forbid people to trespass or to earn their living in the area" $" 24$. The borders were even said to be "golden, silver paths, free for traders" and "the tribal people wandering in the mountain forests were subjects of no power" 25 . Borders were then far from being boundaries: they were frontiers. Lord Curzon depicted this "widely diffused type of ancient Frontier" that was that of "the intermediary or Neutral Zone": "This may be described as a Frontier of separation in place of contact, a line whose distinguishing feature is that it possesses breadth as well as length" 26 .

Boundaries were surimposed on transfrontier routes then, since Southeast Asian frontiers have long been areas linking policies rather than separating them ${ }^{27}$. Colonialism and, later, nationalism, required having boundary lines clearly demarcated: "The major principle behind the Asian frontier system was recognition of the desirability of avoiding direct contact between the administered territories of the various colonial empires concerned"28 (see map 5). In Asia, where the power over individuals was traditionally separated from the power over land, since a subject was bound first and foremost to his lord rather than to a state, modern 
boundaries have "violently and arbitrarily" divided "ethnic peoples into different nationals"29. Hence, the 'external', or alien, may not really be external "while the 'internal' can be made alien or external" as various tribal or refugee people can still experience in Thailand, where many tribal people have spent decades waiting for Thai citizenship and thus have never "belonged" to any state or nation ${ }^{30}$.

As far as the symbiotic relationship between routes and borders is concerned, Abraham and Van Schendel explain how "the act of enforcing a selected flow of people and objects across a border, from border patrols to customs, immediately allows for the possibility of rents to be charged for circumventing these rules and by the same token provides opportunities for smuggling of people and objects across these borders". Of course, "The weight of enforcement is directly related to the prices that can be charged for getting around it - the risk, uncertainty and demand for these flows "across the border" all go into making the border a site for illicitness, from an economic point of view". But, it is also important to understand that "making borders also makes illicit the life activities of border communities" ${ }^{\prime 31}$. Andrew Walker also stresses the fact that " 'open' borders, characterised by flow and passage, usually provide more opportunities for regulation than 'closed' borders"

Not surprisingly, all kinds of smuggling and trafficking flourish in these old frontier areas that often became buffer zones, as had been and still is the case between Burma and Thailand: if the border not only affords some protection to the refugees (from political oppression, economic distress, or even law enforcement) who cross it, it can also help enrich those who do not travel "empty-handed". Thus, a route and an antiroute can engender one another: a closed border can engender a route to transgress it and the rules and restrictions it implies; the presence of a route can call for an artificial antiroute (a checkpoint for example) to monitor or restrict access. Hence the ever-growing diversity of smuggling and trafficking routes and techniques that arise as a consequence of growing markets and increased controls. 


\section{From ancient to modern routes}

That both legal and illegal goods can be traded on the same routes or even together in the same cargo is made easier by the marked increase in movements of goods by land, sea and even air, especially during recent decades. Hiding illegal goods among legal cargo is becoming easier as the global economy unites national and regional markets and as traded goods become more numerous. But modernity draws heavily on history and so-called new routes are often only old routes that have been rediscovered or revived ${ }^{33}$.

In mainland Southeast Asia, as Mya Maung stresses, history teaches us that most of the trading routes between Burma and Thailand are old historic roads, some of them being "the ancient trails used by the Burmese kings when they invaded Thailand" ${ }^{34}$. Mya Maung describes precisely the routes and trading points that allowed black markets to flourish along the Sino-Thai-Indo-Burmese borders: he accounts for "ten different major black market routes between Burma and its three neighbours of China, Thailand, and India"35.

The most active illegal border trade between Burma and Thailand occurred and still occurs at three points: Mae Sai, Mae Sot and Ranong. Goods traded illegally across the ThaiBurmese border were and are still extremely diverse: according to Mya Maung, it was reported that, in the 1970s, Thailand's major exports through the border outposts were "pharmaceutical products, aluminium, wadding rope-coated fabric, boiler machinery, synthetic rubber, and man-made fibre," while in the 1980s, the dominant exports of Thailand were "edible preparations, organic chemicals, iron and steel, manufacturing articles and wadding rope." The dominant imports of Thailand from Burma have been wood and wood articles, especially teak, and gems" ${ }^{36}$.

As for the trade between China and Burma, it developed considerably in the 1990s along the famed Burma Road, across Burma's Shan State toward China's Yunnan Province. Once again, of course, this road and the majority of the Shan trading posts "were not really new, 
their existence dating back to the days of the Burmese kings". In the thirteenth century, "Chinese trading caravans and the invading army of Kublai Khan from China travelled that route" 37 . As with Thailand, goods illegally traded between Burma and China are manufactured in one direction and natural products in the other. Another major trading route between Burma and China lies in Kachin State and was, until the Kachin Independence Army lost control over the jade mines, "the main route for smuggling famous Burmese jade and gems"38.

These old trading routes of mainland Southeast Asia, some of them also linking China to India, have been plied by merchants even when international boundaries were officially closed. Because clandestine border crossings are illegal, the increased risk of such actions raises the value of both the people and goods that accomplish it: having to deal with closed borders, and as some rarefied goods became more expensive and interesting to trade, merchants turned into smugglers and, or, traffickers. Indeed, as many have acknowledged, “making borders engenders illicitness, or in Janet Roitman's words, transgression is productive 39 .

The evolution of drug trafficking in the Golden Triangle has forged new transport routes in the region and has brought abandoned routes back into service, such as those previously used by communist guerrillas. Other pathways were never abandoned. Traditional caravaners such as the Haw of Thailand and the Hui (Panthay) of Burma are very active in the regional illicit drug trade, and still use routes today that their forebears used at the end of the 19th century $^{40}$ (see map 7).

It should be noted here that smuggling and trafficking are old activities that are consubstantial to trading and date back to the earliest regulatory practices meant to restrict and tax commerce. Smuggling actually developed considerably in the context of the British and French colonial tariff regimes. In his extremely valuable study of regulation, trade and 
traders in the borderlands of Laos, Thailand and Burma, Andrew Walker quotes Sidney Legendre, a visitor to Luang Phrabang in the early twentieth century (1936): "The French had placed such a high duty on all goods entering Indo-China that smuggling has become one of the most essential and profitable if not the most honourable of the native trades". Counterfeiting also dates back a long time for Legendre explains that Chinese smugglers "have commenced the importation from China of cheap copies of English, French and American goods" and that he himself bought a Waterman fountain pen and a pair of "Keds" tennis shoes that he found to be "the rankest imitations" $"$. Opium smuggling also preceded opium trafficking: in the context of the British and French colonial monopolies (see map 5), but also of the Siamese monopoly, independent trading was prohibited and opium smuggling became a very profitable enterprise, especially for Yunnanese and Shan caravaners. The British (who sold only Indian opium in their colonial possessions) and the Siamese faced smuggling of Chinese opium into Burma and Siam, while the French faced the same problem in Laos, where they were processing and selling Shan opium from Burma (Kengtung) ${ }^{42}$.

\section{Diversity and complexity of smuggling and trafficking activities}

As we have seen, smuggling and trafficking differ according to the (il)legality of the traded goods. Since the trading activity is basically the same-sending goods illegally across a border-networks and techniques can alternatively or concurrently be used. A great diversity of goods can be legally traded, smuggled and trafficked along one specific route, either separately or concurrently. Trafficking of various illegal goods almost invariably occurs along a single route, in the same cargo or not. This, of course, is not a new phenomenon; for example, drugs-for-arms deals have long been in existence across the world. Obviously, successful smuggling and trafficking routes are very much prone to multiple traffics: in mainland Southeast Asia, as this books shows, most smuggling and trafficking activities appear to occur on the same routes. Overall, the same routes are used for 
the trafficking in small arms, the trade in illegally logged timber, forest products and wildlife, for people smuggling, drug trafficking, the trade in counterfeit goods and for contraband. The coexistence, both in time and space, of various smuggling and trafficking activities, concurrent or congruent, is frequent as illegal trading, as an activity, is not always segmented according to the goods that are illegally traded.

But while a certain degree of coexistence of trafficking activities exists, some of the activities, such as trafficking in nuclear or radiological materials, are at most only suspected. On the contrary, activities such as drug trafficking are much better known. Indeed, "although there is little evidence of involvement of organized criminal groups in nuclear trafficking worldwide, the success with which criminals have smuggled other contraband in South and Southeast Asia-such as narcotic drugs and conventional arms-suggests that nuclear trafficking might be carried out with relative ease, along some of the same routes, by the same criminals, with little hindrance by authorities or permeable border controls" ${ }^{\wedge 3}$. In fact, according to Lyudmila Zaitseva and Kevin Hand, "because of the ease with which organized crime can avoid detection of their illicit activities... [n]etworks trafficking in drugs, weapons, and other illicit commodities are well suited for nuclear smuggling. Their experience in avoiding detection, knowledge of safe routes, protection by corrupt authorities, and established infrastructures can be utilized for trafficking in nuclear and other radioactive material",44.

Another well known fact is that arms can be exchanged for illegal drugs by using the same networks and corridors (especially when rebel armies are involved in production, and, or trafficking of drugs), as has been the case in Afghanistan, in Burma and in northeast India. Human beings, for instance Chinese women, are also smuggled and trafficked into Southeast Asia on the same routes used for drug trafficking to feed, for example, a well-established regional prostitution market (chiefly, Chinese women go south while Burmese heroin goes 
north). Logically, if drugs can be more or less safely trafficked across certain borders and territories, then other items can also follow the same trails, either hidden into large legal cargo and transited across legal entry points, or more or less discretely smuggled and trafficked over long and porous borders, through mountain passes, across rivers or even by unauthorized or unchecked helicopter flights (antiques from Burma being one example). In mainland Southeast Asia smuggling and trafficking is not only made easier by its often mountainous and heavily forested relief but also by its large number of extremely diverse ethnic groups, many of them tribal and semi-nomadic, who straddle international borders (see maps 2, 3,6).

The number and diversity of drug trafficking routes enable other types of smuggling and, or, trafficking activities, sometimes by notorious drug traffickers themselves. For example, trafficking in counterfeit goods has recently increased across the Thailand-Burma border. Based near Thailand's northern border with Burma, some key drug traffickers such as Wei Hsueh Kang have diversified their activities into producing and trafficking pirated pornographic Video Compact Discs (VCDs). This proves interesting since it brings another category of traffickers to the fore: those taking advantage of legal touristic migrations between Tachileck, in Burma, to Mae Sai, in Thailand. The result is an upsurge of trafficking in pirated VCDs. Considering that pirated copies of Hollywood, Thai, Chinese and Taiwanese films can be found everywhere in Tachileck and that "about 1000 tourists cross the border from Thailand to Tachileck every day, rising to 6000 a day during a holiday", Thai authorities estimate that about $80 \%$ of these tourists buy pirated VCDs in Burma and bring them back in Thailand ${ }^{45}$. Also widely available at Tachileck markets are Chinese-made sex stimulants that are not approved by Thailand's Food and Drug Administration and end up being seized by customs officials from returning tourists. As far as counterfeited goods are concerned, a new trend is emerging in Southeast Asia, where drug-resistant malaria is 
widespread and is "fuelling a roaring trade in counterfeit drugs, including the new and effective Artemisinin-based Combination Therapy (ACT) drugs": "Even the Artemisinin compounds-touted as the solution to drug resistance-are being faked in Southeast Asia. The counterfeiters follow where people are buying these drugs, counterfeit the drug and put it in the market" ${ }^{, 46}$. This is a clear and recent example of how drug-trafficking routes can be used for other trafficking activities. In this case, a famous drug trafficker diversifies its production and trafficking activities thanks to the networks and routes he controls. But such routes are being widely used by other smugglers and traffickers, either for the same trades or for different ones.

\section{The scope of illegal trades in Mainland Southeast Asia}

Various examples of smuggling and trafficking activities show that these drug trafficking routes are conducive to multiple trafficking. Mainland Southeast Asia has experienced decades of wars and conflicts, from the Indochina wars, including the Vietnam War, to the internal conflicts in Burma and Cambodia. The armed violence and numerous human rights violations of the Rangoon junta and its army in Shan State, for example, have increased an already constant inflow of Burmese refugees into Thailand. During the past four decades Thailand has become a major country of asylum, receiving some 1.3 million refugees ${ }^{47}$.

Yet, armed conflicts have not only thrown waves of refugees on the roads and across international borders, they have also spurred an international and regional trade in small arms that is still very active and regionally integrated. In the 1990s Cambodia had emerged as a regional market for small arms: "Myanmar rebel groups, secessionists from Sri Lanka and supporters of Acehnese independence movements in Indonesia were among those groups that have were buying weapons from Cambodia's well-established black market"48.

Arms shipments from Cambodia could reach all the way to India, as was allegedly the case in the late 1990s when arms consignments comprising "AK series rifles, mortars, 
landmines, Sten guns and high-powered explosives", meant for various insurgent groups in northeastern India, were said to be coming from Bangladesh, where illegal drugs from Burma and arms from Cambodia crossed their paths: "The drug shipments head towards Jaffna and from there to various destinations in West Asia for entry into the European and US markets. According to intelligence sources, Ranong Island off the coast of Thailand is the staging point for arms shipments that originate from Cambodia and take the sea route through the Andaman Sea to the major receiving point at Cox's Bazar, Bangladesh's southernmost tip". While this route has been used by arms dealers and their end-users for a number of years, the alleged "drug trafficking by the LTTE has added a new dimension" 49 . This maritime route has also clearly been used for trafficking drugs as the January 2001 seizure of heroin and methamphetamine off Surin Island (Thailand) has shown: via the Irrawaddy River Burmese heroin reached the Andaman Sea where fishing boats took it to Ko Surin and unloaded it south of Ranong (see maps 12,15). Ranong is thus not only one of the main trading points for the Burmese black market; it is also a drug-trafficking node and a well-known passage for human smuggling, as testified by its rampant prostitution.

But India's eastern borders with Bangladesh and Burma have also "witnessed smuggling incidents-some of which involved nuclear material of indigenous South and Southeast Asian origin-which since the late 1990s have led authorities to suspect the operation of organized nuclear smuggling rings in the India-Bangladesh border area" ${ }^{\$ 0}$. Indeed, "cesium137, a radioactive material that could fuel a potent Radiological Dispersal Device, was smuggled into Bangkok, Thailand, in 2003. The material was reported to have entered Thailand across the Laotian border and was said to have been of Russian origin. In 2001, equipment stolen from a public works facility in Bangkok contained radioactive material, including cesium-137. In addition, [...] in 1993, police in Hanoi, Vietnam, arrested a 
Vietnamese man for smuggling $10 \mathrm{~kg}$ of uranium from his former workplace in the former Soviet Union",51.

Southeast Asian borders are also known for other thriving smuggling and trafficking activities. Burmese teak (Tectona grandis), for example, has long been increasingly logged and exported to Thailand, some of it smuggled, since in 1989 Thailand forbade its own teak from being cut. Farther north, on the Chinese-Burmese border, it is the Wa hills that are being deforested, this for the economic benefit of China and in the context of a hastened opium suppression programme ${ }^{52}$. Much has been said on Burma's balance of payments and the fact that it shows hundreds of millions of dollars in unexplained foreign financial inflows. The most widely accepted explanation was that heroin exports were the largest contributor to the country's economy. However, illegal timber exports are likely to have contributed tens of millions of dollars to these financial inflows. "As well as deliberately concealed exports, another explanation for the export-import discrepancies ... is that substantial timber exports are taking place from territories outside the control of the Forest Department. Both explanations are probably valid. Burma's biggest customers (China, India, and Thailand) are not only its neighbours, thus facilitating unofficial cross-border trade, but also report the greatest differences between their imports and Burma's declared exports. Thailand reported more than four times Burma's declared exports in 1994 and double the declared exports in 1995; India did not provide any statistics for 1994, but in 1995 its declared imports were 30 times greater than Burma's declared exports. Burma reported no exports to China in 1995, though China declared imports of more than $500,000 \mathrm{~m}^{3,, 53}$.

According to the Chiang Mai based Lahu National Development Organisation, "There is hardly any teak forest remaining [in Eastern Shan state, Burma], but other kinds of hardwood, pinewood and fragrant sandalwood are still in great demand". The LNDO also reports that "[m]ost of the ceasefire groups and militia are involved in logging in their areas, some in 
conjunction with wealthy businessmen from the cities" and that "[t]he UWSA's Hong Pang company is currently the main organisation in eastern Shan State carrying out logging. They have their own logging equipment, and also sub-contract other local or foreign (Thai or Chinese) loggers with equipment to carry out the logging" 54 . More of Burma's natural resources are being plundered in the country's peripheries as numerous non-timber forest products are also being removed from Burma's luxurious forests. The LNDO also mentions that: "There is a huge demand from China for wildlife and forest products, mainly for medicinal purposes. These include tortoises, bears' gall bladders, snakes, otter skins, pangolin scales and wild orchids. Despite the fact that many of these species are endangered and trade in them is prohibited in Burma, there exists a thriving black market network to locate and export the various items. The main dealers are Chinese businesspeople living in towns such as Tachilek and Kengtung. They send out representatives to villages, where they place orders for certain products with local agents. Villagers are told that if they can find the products, they will receive a particular amount of money, for example up to 20,000 kyat (approx US\$20) per 10 tical (approx $160 \mathrm{~g}$ ) of bear's gall bladder or 150000 kyat (approx US\$140) per viss $(1,6 \mathrm{~kg})$ for first class orchids" 55 . The wildlife of mainland Southeast Asia has already considerably suffered from the wide-scale hunting, poaching, and trafficking of numerous species, reorienting the plunder and trade toward countries that have been somehow spared until recently. Hence, "as neighbouring countries have exhausted their own valuable natural resources, the price for Cambodia's last populations of tigers, elephants, and bears has soared to levels undreamed of even a decade ago". But Cambodia is not the only country concerned: "as demand for wild animals has grown in far off places, new supply routes have opened up in Asia", most notably in Burma, and "the supply routes are growing bigger and more sophisticated by the day" ${ }^{, 56}$. As suggested by the above-mentioned examples, smuggling and trafficking activities are widespread and extremely diverse in Southeast Asia. 


\section{Trafficking synergies or isolated trends?}

There is a distinction that goes beyond that made between smuggling and trafficking. Indeed, smuggling and trafficking vie not only on newly generated resources such as illegal drugs but also and even more on non-renewable natural resources: most of smuggling and trafficking activities thrive on what can be designated as predatory economies and activities, that is, most notably, plundering of natural resources. What is rarely acknowledged is that such trading can prove much more detrimental to the environment and to human societies than the production of, and trafficking in, illegal drugs (the environmental costs of which should not be ignored either) or counterfeit items (even though counterfeit mechanical parts and medical drugs present obvious dangers). But since smuggling and trafficking are of concern for source, transit, and destinations countries, one has to dissociate the impacts and consequences of these trades according to their very nature and extent. For instance, human trafficking can have extremely detrimental social and health consequences in source as well as in destination countries. As for the trade in exotic timber and rare animal species, it can create environmental havoc in source countries (forest depletion but also landslides, vulnerability to tidal waves, etc.) but is unlikely to have dramatic consequences in destination countries, at least until a probable global impact is felt in these countries.

Moreover, some law enforcement activities can have rather perverse and so-called unintended consequences, fuelling other illegal activities than the targeted one as producers and, or, smugglers and traffickers resort to alternative economic activities to make up for lost revenues. For example, the "war on drugs" can clearly be counter-productive in terms of drug production, "resulting in perverse incentives for farmers to grow more drugs (e.g., in Colombia), displacement of production to more remote areas, and fuelling of violence and insecurity (Peru, Bolivia, Colombia), which in several cases forced the eradication policy to be reversed and led to adverse political outcomes" ${ }^{\text {57 }}$. No doubt, such a phenomenon occurs in 
Asia too, where the failure to provide economic alternatives to opium production before eradicating poppy crops also can have a devastating impact on the impoverished rural people who depend on the illegal opium economy for their livelihood ${ }^{58}$, and thus foster other drugtrafficking activities (heroin in lieu of opium, methamphetamine in lieu of opium and, or heroin) such as human trafficking, widespread logging, trafficking in rare species, etc.

Other such synergies can be suspected and still need to be properly documented and understood. For example, various trades and movements can be linked: the sex trade can, to some extent, be nurtured by ill-designed and ill-implemented anti-drug policies, thus worsening an AIDS pandemic that, in Asia, grows mostly through intravenous drug use. The AIDS pandemic can also be suspected of spurring child prostitution as it is likely that the worldwide explosion of child prostitution that happened after 1985 has been partly driven by the fear of AIDS (but also by a growing worldwide tourism industry that made sex tourism more affordable). Moreover, when eradication of illegal crops such as opium is favoured against the development of alternative livelihoods, "unintended" consequences such as accelerated deforestation and other predatory activities are very much likely to occur.

As for small arms smuggling and trafficking, mostly of ordinary conventional weapons, it is responsible for the vast majority of casualties in the world's conflicts and thus for the death, wounding and uprooting of a countless number of people each year ${ }^{59}$. In Southeast Asia, as is now well known, decades of armed conflicts (in Vietnam, Laos, Cambodia, Burma) have spurred the production and traffic of opium, heroin and, more recently, methamphetamine. But armed conflicts have also put hundreds of thousands of refugees on the move and across the national borders of the region, creating favourable conditions for the growth of black markets, the regional sex trade, and drug trafficking and consumption.

Of course, demand from buyers around the world plays a significant role by fuelling these trades. But poverty and underdevelopment as well as economic disruptions, political crises, 
armed conflicts and natural catastrophes create local, national and regional contexts and synergies that can push people into smuggling and trafficking. In Southeast Asia as in the rest of the world the smuggling and trafficking phenomenon is extremely diverse and complex. Complex yet unaccounted, for synergies are undoubtedly at work between different smuggling and trafficking activities. The case of mainland Southeast Asia shows a complex reality in which every smuggler or trafficker may not be a versatile and diversified merchant, but where many illegal trades coexist and can compete with and, or, benefit from each other, though to an extent that will not be satisfactorily known and understood until further research is conducted through specific case studies.

\section{Five authors, six case studies}

This volume addresses the diversity and complexity of illegal trading in mainland Southeast Asia, not by presenting an exhaustive state of illegal trades but by surveying the scope and multi-fold nature of the phenomenon. As an atlas, it focuses on the routes used to carry various illegal trades in the region. The attempt here has been to gather contributors who could write about illegal trades from a variety of disciplines and could contribute to the mapping of the smuggling and trafficking routes according to their respective fields of expertise. It seemed logical, if not necessary, to draw maps of the routes described in the chapters of this volume, so that the readers could better visualise how illegal trades organised themselves spatially, but also to enable a comparison between the different routes followed by the different trades. In the end it appears that the different trades tend to follow the same routes, with the same main cross border points being used for either drug trafficking, human smuggling or trafficking, the illegal trade in wood, wildlife, small arms, and counterfeit goods (see map31). In fact the smuggling and trafficking routes correspond to a great extent to the main transport corridors of the region (compare maps 8 and 31): basically the historic trading roads of mainland Southeast Asia, India, and China (map 7) that were included in 
both the Asian Highway Network project (1959) and the more recent Greater Mekong Subregion corridor project (1992) (map 8).

Mapping smuggling and trafficking routes is a difficult and delicate task, not only because such activities are meant to be concealed, but also because of difficulties and limitations inherent to the cartographic process. Mapping is not very different from writing in its way of describing and representing reality, yet it is too often read as being not a representation of reality but the real itself. The map, writes Marco Quaggiotto, "is not only a passive representation of reality but a tool for the production of meaning", just like any text: "The map as narration, is thus the expression of a communicative purpose" 60 . But "a representation is reproduced rather than reality" stresses Geoff King, who also warns that, too often, in the cartographic process, "the distinction between reality and representation becomes blurred" ${ }^{\prime 61}$. Quaggiotto rightly explains:

"Just like a text, the map makes selections on reality, distorts events, classifies and clarifies the world in order to better tell a particular aspect of a territory, an event, a space. When used with malice, it can hide, conceal, falsify or diminish a reality through the construction of an ideological discourse, in which the communicative aims are hidden to the user. In this context, the term 'map' is a synonym of visual narration of space: a cultural artefact created by an author to describe a space according to an objective" ${ }^{\mathrm{6}}$.

In fact, cartography, like any discourse, has its own rhetoric, that is, "a linguistic technique used to select and process elements of reality in order to transform them in an effective speech"63. This is actually what Van Schendel aims at when he criticizes what he calls a "surfeit of arrows". Arrows, bodies and heads, are of course useful tools resorted to by the cartographer while mapping smuggling and trafficking routes, something that Van Schendel denounces not only because "the arrow is a godsend for those wishing to represent illegal flows in a threatening manner" but also because: 
"The discourse on illegal flows focuses on the (ill) effects of the flows at their points of destination but has little time for possible effects at the various staging posts, including borders: it is the head of the arrow rather than its body that we are invited to concentrate on" $" 64$.

Arrows were of course used in this atlas, not "to represent illegal flows in a threatening manner" but because the arrow is a "discursive tool that conveys the notion of motion, stimulus, and target as perhaps no other graphic code could" ${ }^{\prime 65}$. Also, borders were drawn in a very usual way by using thin lines that can also be said to misrepresent the reality of borderlands and frontiers (something that Van Schendel does not criticize). An effort was made, however, to represent smuggling and trafficking as cross border activities by detailing as many border towns, staging posts, and hubs as possible (Tachileck - Mae Sai and Muse Ruili for example). In any case, cartography is obviously "an art of compromise and partial solutions" depict or represent. Van Schendel is right when he writes that "bold arrows hide more than they reveal" as many maps of flows are drawn with broad arrows showing only directions and not actual routes or roads, something that was avoided in this atlas. This is actually why arrows in this atlas are not "quick stopgaps" that hide "our lack of detailed knowledge, dramatizing and simplifying processes that we understand at best in outline"67. In fact, here, the maps are nothing more, or less, than the graphic equivalent to the texts that they illustrate. Texts and maps complement one another not only by helping the readers to place the many locales in the region but also by showing the limited extent of our knowledge and of our understanding of what stay, in the end, complex and constantly changing phenomena.

To some extent the maps of this atlas look alike: the main smuggling and trafficking routes are often the same no matter what is actually being smuggled or trafficked. Yet, smuggling and trafficking sometimes occur in opposite directions along the very same routes: for 
example, drugs and arms often go opposite ways. And wildlife and timber go from Burma to China along the same routes used to introduce counterfeit goods from China to Burma. The reader also needs to keep in mind that smuggling and trafficking can, and most likely do, also occur in the blank spaces on the maps: if anything, blank spaces represent more a lack of hard evidence than an absence of smuggling or trafficking routes. As the English poet William Cowper (1731-1800) wrote, "Absence of proof is not proof of absence”.

The book is divided in 7 chapters and 30 maps. In chapter 1, I, as a geographer, introduce this volume by stressing how mainland Southeast Asia shows a complex reality in which every smuggler or trafficker may not be a versatile and diversified merchant, but where many illegal trades coexist and can compete with and, or, benefit from each other. In chapter 2, I provide a broad history and geography of the drug trafficking routes in and out of the socalled Golden Triangle, whose opium and heroin production and networks have played a significant role in both the regional and world history. I detail the old and new drug trafficking routes and conclude that "drug trafficking is only one aspect of the drug economy and while the goals of a drug-free world or a drug-free ASEAN will never be reached, efforts can and should be made to minimize the harms caused by illegal drug production, trafficking, and consumption". Chapter 3, by anthropologist David Feingold, focuses on human smuggling and trafficking, a highly complex trade that has many historical and social and political causes and implications. Feingold calls for the need to develop an epidemiology of trafficking and warns against "more restrictive border security that will push greater numbers of migrants to depend on traffickers and smugglers to move them across borders". In chapter 4, David Capie, a political scientist, examines the illegal trade in small arms, obviously a key topic in mainland Southeast Asia with its many passed and ongoing armed conflicts. As Capie explains, "while there has been impressive rhetoric about the need to tackle the illicit arms trade in the region, there has been much less in the way of practical action". He 
concludes that "there is little evidence that weapons trafficking will disappear from the regional landscape any time soon". Chapters 5 and 6, by political scientist Vanda FelbabBrown, examine two other key - and interrelated - topics in mainland Southeast Asia: illegal logging and wildlife trafficking. Since illegal logging accounts "for a very large portion of forest destruction in the region", Felbab-Brown explains that "law enforcement can be tightened, regulatory regimes improved, demand for certified timber encouraged, and demand for timber overall reduced" but that it remains to be seen "whether these measures can be developed and adopted on a sufficient scale to preserve the world's natural biologically-rich forest ecosystems that are collapsing at an unprecedented rate". Similarly, she stresses how, "sadly, the overall prospects for designing policy interventions in a way that can achieve substantial reduction in the illegal trade in wildlife in Southeast Asia are not high". In Chapter 7, Bertil Lintner, a journalist, surveys the trade in counterfeit goods and in contraband, two prominent activities in mainland Southeast Asia. Lintner estimates that "there is little that can be done to stop the flow of consumer goods-whether real or counterfeit—-from China to Southeast and South Asia".

Some of mainland Southeast Asia's countries rank among the world's most corrupt countries, with Burma being perceived as the third most corrupt country in the world, after Afghanistan and Somalia (in 2009 and according to Transparency International). As for the others, Laos ranked 158, along with Cambodia, while Vietnam ranked 120, and Thailand 84, along with India. China fared a bit better as the world's 79th most corrupt country. On the other end, Singapore ranked as the world's third least corrupt country.

Therefore, Cambodia provides a great case study of how corruption undermines antitrafficking efforts: it is not usually perceived as being as corrupt as Burma but still ranks as one of the most corrupt countries in the world. Cambodian corruption clearly hinders antitrafficking efforts at various levels and stages, including at international borders. This was 
verified during three field trips undertaken in Cambodia in 2010 and 2011. Nine points of entry into Cambodia were visited, on the coast (the deep water sea port of Sihanoukville and the Oknha Mong Port near Keo Phos) and the borders of Thailand (Poipet, Cham Yeam, Prom), Vietnam (Bavet, Tropieng Phlong, Tropieng Sre), and Laos (Dong Kralor). No matter what material or human means were deployed at these points of entry, almost no seizures of any kind were made during the last years, according to interviewed officials. For example, not one single seizure of illegal goods was made using the container scan of Sihanoukville since China offered it to Cambodia in 2005. Seizures of illegal drugs were almost unknown at any of the nine aforementioned cross border checkpoints, except for small quantities years ago. Seizures seemed virtually nonexistent and the Cambodian customs appeared to be mostly concerned with collecting tax and duties while the border police and the immigration police did not seem to be more efficient at intercepting traffickers or smugglers. But corruption is not the only issue hindering anti-trafficking efforts in Cambodia, or in the other countries of the region. In fact, the Border Liaison Offices (BLO) (see map 9) set up by UNODC in Cambodia, if functioning at all, did not seem to be very efficient either. The staff of the Poipet BLO was actually absent (reportedly in Phnom Penh) when visited in late 2010 (although the visit had been planned in accordance with UNODC) and interviews conducted with senior administrative authorities revealed that bilateral meetings or communications rarely happened and never yielded any result. Corruption is obviously a major hindrance to counter-trafficking policies in mainland Southeast Asia but ill-designed programs also bear responsibility for the overall failure of interdiction efforts, especially when development programs aimed at strengthening anti-trafficking measures fail to integrate anti-corruption measures, such as in Cambodia.

In the end it seems that while national governments, ASEAN, UNODC, and NGOs have made and keep making efforts against trafficking and smuggling, no significant achievement 
will be reached without addressing corruption and its causes. In a similar way, addressing illicit drug production in the region will only be possible by addressing poverty, i.e. the main driver of illegal opium production. Corruption and illegal opium production actually happen to have the same root causes: poverty and the desire for a better life, but also violence (repression, persecution, war, genocide) and environmental degradation. Suppressing smuggling and trafficking altogether in mainland Southeast Asia (or anywhere else for that matter) will never be possible for illegal trading is the necessary corollary of commerce. But reducing the scope of smuggling and trafficking is something that can be achieved if the policies and measures devised to address the problem also aim at the root causes of the phenomenon, that is, poverty and corruption.

\footnotetext{
${ }^{1}$ Tom R. Naylor, 2002, Wages of Crime: Black Markets, Illegal Finance, and the Underworld Economy, Ithaca, Cornell University Press: $\mathrm{x}$.

${ }^{2}$ Itty Abraham, Willem van Schendel (Ed.), 2005, Illicit Flows and Criminal Things. States, Borders, and the Other Side of Globalization, Bloomington, Indiana University Press: 10.

${ }^{3}$ Abraham, Willem van Schendel (Ed.), 2005: 14.

${ }^{4}$ Mahnaz Z. Ispahani, 1989, Roads and Rivals: the Politics of Access in the Borderlands of Asia, London, I.B. Tauris \& Co Ltd Publishers.

5 David Bevan, Paul Collier, Jan Gunning, 1998, Black Markets and Black Goods, Oxford University Institute of Economics and Statistics, mimeogr.

${ }^{6}$ Abraham, Willem van Schendel (Ed.), 2005: 4.

7 For further developments regarding illicitness in international trade, see: Marie-Angèle Hermitte, L'illicite dans le commerce international des marchandises, in Philipe Kahn et Catherine Kessedjian, 1998, L'illicite dans le commerce international, Dijon, University of Burgondy-CNES ("Travaux du Centre de recherche sur le droit des marchés et des investissements internationaux", 16): 109-175.

8 Brian Iselin and Melanie Adams, 2003, Distinguishing between Human Trafficking and People Smuggling, UNODC, Bangkok, 10 April 2003.

9 US Department of State, Trafficking in Persons Report, 2004: http://www.state.gov/g/tip/rls/tiprpt/2004/

10 Xin Ren, 2004, Trafficking in Children: China and Asian Perspective, California State University, Sacramento, Conference on Making Children's Rights Work: National \& International Perspectives, International Bureau for Children's Rights, Montreal, November 20, 2004: 1.

11 Xin Ren, Trafficking in Children: China and Asian Perspective: 2.

12 Xin Ren, Trafficking in Children: China and Asian Perspective: 5.

13 Vitit Muntarbhorn, "Tackling the demand factor for child sex", Bangkok Post, 30 April 2005.

14 http://www.ecpat.net/eng/index.asp

15 Reuters, "Sex trafficking growing in Southeast Asia", 26 April 2005.

16 International Labour Organisation, A global alliance against forced labour, Global Report under the Followup to the ILO Declaration on Fundamental Principles and Rights at Work 2005, International Labour Office, Geneva, May 2005.
} 
17 Robert L. Canfield, Ethnic, Regional, and Sectarian Alignments in Afghanistan, in Ali. Banuazizi and Myron Weiner (Eds), The State, Religion, and Ethnic Politics. Afghanistan, Iran, and Pakistan, 1986 : 97.

18 M.E. Edwards, J.B. Baumann, 1977, “An Eye for an eye: Pakistan's Wild Frontier”, National Geographic, January $1977: 122$.

19 Mahnaz Z. Ispahani, 1989: 141. Regarding borders and trafficking routes in Asia, see also: Pierre-Arnaud Chouvy, 2002, Les territoires de l'opium, Paris, Olizane, 2002; and Pierre-Arnaud Chouvy, 2009, Opium. Uncovering the Politics of the Poppy, London / Cambridge, I.B. Tauris / Harvard University Press. See also www.geopium.org.

${ }^{20}$ David Ludden, 2003, "Presidential Address: Maps in the Mind and the Mobility of Asia", Journal of Asian Studies, Vol. $62 \mathrm{n}^{\circ}$ 4, November 2003: 1062.

21 Mahnaz Z. Ispahani, 1989:2-3.

22 Mahnaz Z. Ispahani, 1989: 7.

23 Mahnaz Z. Ispahani, 1989: 3.

${ }^{24}$ Thongchai Winichakul, 1994, Siam Mapped. A History of the Geo-Body of a Nation, Bangkok, Silkworm Books: 73.

25 Thongchai Winichakul, 1994: 73.

26 Text of the 1907 Romanes Lecture on the subject of Frontiers by Lord Curzon of Kedleston, Viceroy of India (1898-1905) and British Foreign Secretary 1919-24): Website of The International Boundaries Research Unit (http://www-ibru.dur.ac.uk/docs/curzon1.html).

27 Pierre-Arnaud Chouvy, 2002.

28 Alastair Lamb, 1968: Asian Frontiers. Studies in a Continuing Problem, London, Pall Mall Press: 62-63.

29 Thongchai Winichakul, 1994: 164.

30 Thongchai Winichakul, 1994: 170.

31 Willem van Schendel, Itty Abraham, 2000, "Beyond Borders: (Il)licit Flows of Objects, People, and Ideas", New York, Social Science Research Council, Discussion Paper.

${ }^{32}$ Andrew Walker, 1999, The Legend of the Golden Boat. Regulation, Trade and Traders in the Borderlands of Laos, Thailand, China and Burma, Honolulu, University of Hawai'i Press: 16.

33 Pierre-Arnaud Chouvy, 2002.

34 Mya Maung, 1991, The Burma Road to Poverty, New York, Praeger: 210.

35 Mya Maung, 1991: 210.

36 Mya Maung, 1991: 211.

37 Mya Maung, 1991: 213.

38 Mya Maung, 1991: 214.

39 Willem van Schendel and Itty Abraham, 2000.

40 Pierre-Arnaud Chouvy, 2002 ; Pierre-Arnaud Chouvy and Joël Meissonnier, 2004, Yaa Baa. Production, Traffic and Consumption of Methamphetamine in Mainland Southeast Asia, Singapore, Singapore University Press,.

${ }^{41}$ Andrew Walker, 1999: 49.

${ }^{42}$ Andrew Walker, 1999: 49; Alfred McCoy, 1972, The Politics of Heroin in Southeast Asia, New York, Harper \& Row; Robert B. Maule, 1992, "The Opium Question in the Federated Shan States, 1931-36: British Policy Discussions and Scandal", Journal of Southeast Asian Studies, Vol. 23, N 1, pp. 14-36.

43 Andrew Prosser, 2004, Nuclear Trafficking Routes: Dangerous Trends in Southern Asia, Special report of the Center for Defense Information, 22 November 2004.

44 Lyudmila Zaitseva, Kevin Hand, "Nuclear Smuggling Chains", American Behavioral Scientist, 46.6, February 2003: 822-844.

45 Bangkok Post, "Drug kingpin moves into porno business", 20 April 2005.

46 Agence France Presse, "Drug resistant malaria haunts Southeast Asia, fuels illicit trade", 26 April 2005.

472011 UNHCR Country Operations Profile - Thailand: http://www.unhcr.or.th/what (page visited on 1 February 2011).

48 Jane's Sentinel Security Assessment, “Cambodia”, Southeast Asia, Issue Twelve, London, Jane's Information Group, 2003: 71.

49 Outlook India, “Arms, Drugs, and the Man”, 26 March 2001.

50 Andrew Prosser, 2004.

51 Andrew Prosser, 2004.

52 Pierre-Arnaud Chouvy, "The dangers of opium eradication in Asia”, Jane's Intelligence Review, Vol. $17 \mathrm{n}^{\circ}$ 1, January 2005, pp. 26-27; Pierre-Arnaud Chouvy, "Myanmar's Wa: Likely losers in opium war", Asia Times, 24 January 2004.

53 World Resource Institute, The Regional Timber Trade in Southeast Asia, http://www.wri.org/ffi/burma/ timtrade.htm, page visited on 21 March 1999. 
54 Lahu National Development Organisation, 2004, Aftershocks along Burma's Mekong, http://www.ibiblio.org/ obl/docs/Aftershocks.html (page visited on 27 April 2005).

55 Lahu National Development Organisation, 2004, Aftershocks along Burma's Mekong, http://www.ibiblio.org/ obl/docs/Aftershocks.html (page visited on 27 April 2005).

56 Ban Davies, Patrick Brown, "On the Trail of the Wildlife Traffickers", The Irrawaddy, April 2005: http:// www.irrawaddy.org.

57 World Bank, Afghanistan: State building, sustaining growth, and reducing poverty. A country economic report, 9 September 2004: 87-88.

58 Pierre-Arnaud Chouvy, "The dangers of opium eradication in Asia", Jane's Intelligence Review, 1 January 2005: 26-27.

59 From the arms-trade page of the Center for Defense Information: http://www.cdi.org

${ }^{60}$ Marco Quaggiotto, 2008, "Knowledge cartographies: Tools for the social structures of knowledge", Changing the Change Conference, Turin 2008, http://www.knowledgecartography.org/PDF/knowledge-cartographies.pdf (page visited on 21 April 2011): 4.

${ }^{61}$ Geoff King, 1996, Mapping Reality. An Exploration of Cultural Cartographies, New York, St Martin's Press: 9.

${ }^{62}$ Marco Quaggiotto, 2008: 4-5.

${ }^{63} \mathrm{Ibid}$

${ }^{64}$ Willem van Schendel, 2005, "Spaces of Engagement", in Itty Abraham, Willem van Schendel, Illicit Flows and Criminal Things. States, Borders, and the Other Side of Globalization, Bloomington, Indiana University Press: 41.

${ }^{65} \mathrm{Ibid}$.

${ }^{66}$ Marco Quaggiotto, 2008: 7.

${ }^{67}$ Willem van Schendel, 2005: 42. 